\title{
Women's Empowerment through Small-Scale Dairy Farming in Selected Areas of Bangladesh
}

\author{
Sarah Yasmin ${ }^{1} \&$ Yukio Ikemoto ${ }^{2}$ \\ ${ }^{1}$ Department of Agricultural and Resource Economics, Graduate School of Agricultural and Life Sciences, The \\ University of Tokyo, Japan \\ ${ }^{2}$ Institute for Advanced Studies on Asia, The University of Tokyo, Japan \\ Correspondence: Sarah Yasmin, Department of Agricultural and Resource Economics, Graduate School of \\ Agricultural and Life Sciences, The University of Tokyo, Bunkyo-ku, Tokyo 113-8657, Japan. E-mail: \\ jesy099@yahoo.com
}

Received: September 6, 2015 Accepted: September 23, 2015 Online Published: October 21, 2015

doi:10.5539/ass.v11n26p290 URL: http://dx.doi.org/10.5539/ass.v11n26p290

\begin{abstract}
In this study, we investigated the role of small-scale dairy farming and related factors in promoting empowerment among women in the Salakandi (V1) and Binpara (V2) villages in the Mymensingh district of Bangladesh. Data were collected from 50 rural women involved in dairy farming practices in each village through direct interviews using questionnaires. A combination of criteria was modeled using Multiple Linear Regression, revealing that, for all criteria, women from V1 exhibited greater empowerment than women from V2. Through small-scale dairy farming, rural women from V1 were able to increase their confidence and decision-making power with regard to their household and personal care and experienced increased self-esteem, expansion of their social circles, and ultimately enhanced empowerment through the breakdown of traditional socio-cultural norms. Thus, the expansion of small-scale dairy farming in other rural areas of Bangladesh is likely to contribute to the empowerment of more rural women.
\end{abstract}

Keywords: Bangladesh, dairy farming, rural women, women's empowerment index

\section{Introduction}

Women's empowerment is one of the significant issues for upholding status of rural women in Bangladesh. Women's empowerment involves improving decision-making, control over income, awareness about personal rights and freedom, improving position in the family, and in general the confidence of rural women in their capabilities. In Bangladesh, rural women are largely deprived of autonomy as their lives are controlled by male governance in the patriarchal society. The women are subjected to aggressive behavior at the hands of their husbands and other male members of husband's family. Due to long-standing traditions in rural Bangladesh society regarding the role of women, a husband will commonly seek to limit the autonomy of his wife in all regards and will not show affection or respect, in contrast to standards in many western cultures. Following the marriage, a woman enters her husband's house and immediately takes on responsibility for all household work. Her most important duty, however, is to bare a male child. These women are not at liberty to express opinions in front of their husbands or to make their own decisions and instead must obey any rules dictated by their husband or members of the husband's family. Rebellion against the mandates of the husband can result in physical and mental and even threats of divorce. This oppression is a common experience for every woman in the traditional rural Bangladesh society and highlights the importance of fostering women's empowerment to remove gender inequality both within the family unit and in society. Because rural Bangladesh society seeks to suppress even female independent thought, if these women will successfully escape the patriarchal society, they must first be taught and encouraged in building a strong independent mindset. Only by establishing a new standard of personal independence will these women gain confidence in their own capacity for governing their lives and thereby develop the strength to stand strong in the face of subsequent oppression.

Additionally, gender equality and empowerment of women are vital to achieve sustainable improvement in the rural society (Afzal et al., 2009). Shefner-Rogers et al. (2009) stated that women's empowerment is the construction of a route to foster women's ability to be self-reliant and to improve internal power. Promoting the participation of rural women in income generating activities is one important route toward encouraging 
independence and facilitating empowerment.

Indeed, more recently, the situation within rural societies in Bangladesh is changing, due to increasing involvement of rural women in economic activities, which can foster the development of increased self-confidence, self-motivation, personal and economic mobility, decision-making ability, and general autonomy. Through their participation in income generating activities like small-scale dairy farming, rural women are able to transcend traditional barriers and have the potential to escape oppression such as domestic violence that limits their empowerment. Small-scale dairy operations run by rural women are growing increasingly popular in Bangladesh due to the limited costs of rearing dairy animals on personal homesteads. Currently, small-scale dairy farming is considered one of the best ways for these rural women to utilize their limited resources and to develop skills that will contribute to their empowerment. The goal of the present study is to quantify the empowerment of rural women in the Bangladesh villages Salakandi (V1) and Binpara (V2) and to identify key factors affecting their empowerment.

\section{Review of Literature}

A widely-accepted definition of women's empowerment remains intangible given the popularity and wide use of the term in academic and general sectors. However, discussions of women's empowerment often place emphasis on decision-making roles, economic self-reliance, legal rights to equal treatment, education, and inheritance, and protection against discrimination. Reasonably so, then, women's empowerment has been described as a process through which women gain authority in previously restricted areas of their lives (Kishor \& Gupta, 2004; Haque et al., 2011) and whereby women direct their lives with the purpose of changing inferior status (Keller \& Mbwewe, 1991).

Women's empowerment may also be generally defined as an ongoing process where in a woman acquires the ability to define and successfully pursue personal objectives (Kabeer, 1999). Page and Czuba (1999) similarly defined empowerment as a multi-dimensional process that helps people gain control over their own lives (see also Sen, 1999; Malhotra, 2003) and also fosters empowerment in communities and society.

According to Kishore and Lekha (2008) empowerment entails a woman's increased control over her life, body, and external environment, while Charmus and Wieringa (2003) note that it is a process that encompasses the development of consciousness, choice, resources, voice, agency, and participation. Hashemi and Schuler (1993) identified a number of domains in which women have traditionally been stripped of autonomy, such as physical mobility, financial security, and freedom in social interactions, thus as Batiwala (1994) highlighted, women's empowerment must encompass a direct challenge of institutions of power (e.g. family, media) and power structures (e.g. legal, economic) toward the goal of gaining autonomy. Similarly, Mujahid et al. (2015) highlighted the importance of economic and social equality for women's empowerment in Pakistan. Economic empowerment is fostered by decreases in poverty, access to credit programs, and lucrative work while social empowerment encompasses education, health care access, and other social opportunities. Workshops and media campaigns can further encourage rural women to break away from traditional views.

Within Bangladeshi society, empowered women possess freedom for self-development and decision-making and equal access to domestic and community resources (Kumar et al., 2013). Nazneen et al. (2011) examined women's empowerment in post-independence Bangladesh and noted improvements in female education, treatment in health facilities, and participation in the labor force. However, due to traditional patriarchal attitudes, social and financial inequalities still prevail among men and women. Similarly, Haque et al. (2011) used three dimensions to define women's empowerment index and found that economic and family decision-making authority is satisfactory while mobility is very low, and negative social views about female autonomy are still prevalent.

Islam et al. (2014) examined the impact of microcredit on women's empowerment in rural Bangladesh, defining empowerment with the dimensions of economic and household decision-making, mobility, property ownership, and social awareness. Their results showed that the microcredit program was positively associated with each dimension of women's empowerment and overall empowerment. Sultana and Hossen (2013) also investigated the role of employment in women's empowerment in Khulna, Bangladesh and found that employed women were more empowered than the unemployed, with age, educational access, and household income also having a significantly positive effect on women empowerment. Islam et al. (2012) also identified that homestead poultry rearing among rural women in Bangladesh promotes empowerment by encouraging independent decision-making and increased involvement in family affairs.

Based on this collection of previous research, we identified two factors that are important to consider in the measurement of women's empowerment. First, empowerment is not directly measureable and must be quantified 
via other indicators. These indicators have to be selected to measure agency, such as participation in household decision-making, spending money and freedom of mobility. Second, women's empowerment is a multidimensional system. Accounting for these dimensions is important in more clearly offering a potential roadmap for measuring women's empowerment. This study is a unique contribution to studies on rural women's empowerment in two respects. This study is the first to provide a comparison of women's empowerment through small-scale dairy farming in two villages of the Mymensingh district in Bangladesh. This study is also the first to assess different factors that are anticipated to be important in women's empowerment through small-scale dairy farming in these selected areas of Bangladesh.

\section{Research Methodology}

\subsection{Selection of the Study Area and Data Collection}

The field research was performed in 2014 in the villages Salakandi (V1) and Binpara (V2) of the Mymensingh district of Bangladesh. These locations were selected based on their dense concentrations of dairy farms. Small-scale dairy farm owners constituted the population of the present study. 50 households actively engaged in small-scale dairy farming from each village were randomly selected for interviews. Research data was collected by direct observation of women interviewees and through their interview questionnaire responses. All collected data was entered into Microsoft Excel.

\subsection{Construction of a Women's Empowerment Index}

In this study, women's empowerment was quantified by making a women's empowerment index using the dimensions in accordance with Malhotra (2003), Haque et al. (2011), and Mahmud et al. (2012). The dimensions used are: decision-making, economic empowerment, social empowerment, legal empowerment and psychological empowerment. Each dimension further contains several indicators which have been identified according to Hashemi et al. (1996), Schuler et al. (2010), and Islam et al. (2012). Figure 1 represents these different dimensions with their relevant indicators for the eventual construction of the women's empowerment index. Questionnaire responses were based on a four point Likert scale $(1=$ not at all, $2=$ to some extent, $3=$ to an average extent and $4=$ to a great extent). In order to standardize the results and generate a scale with minimum and maximum levels of empowerment, the score for each dimension was assigned a maximum value of 1 for highest empowerment and minimum value of 0 for lowest empowerment. Thus the standardized scale ranges from zero to one.

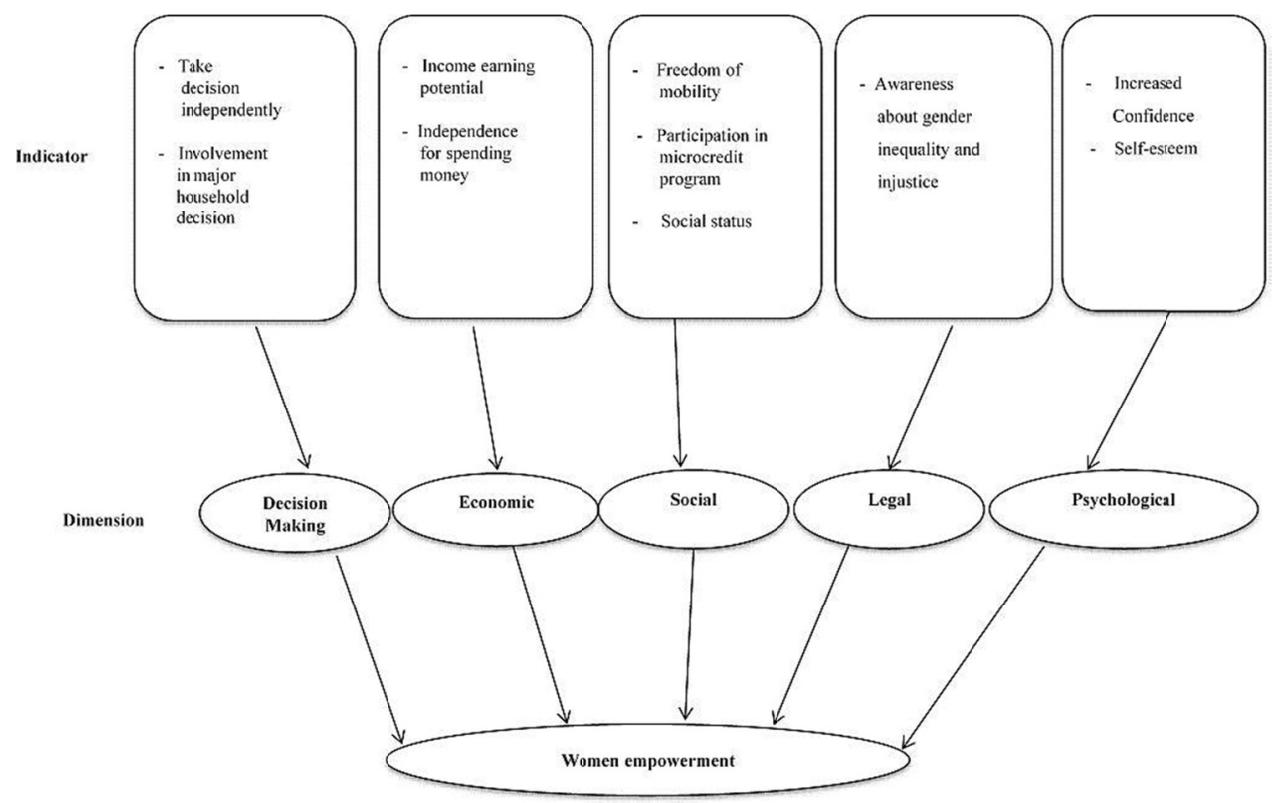

Figure 1. Conceptual framework of the women's empowerment index employed in this study, including dimensions and indicators

\subsubsection{Decision-Making Index}

Two indicators have been used for the dimension of decision-making. Empowerment in decision-making is represented by the following formula: 


$$
\begin{aligned}
& \text { Decision-making index, } \mathrm{I}_{1}=\frac{X 1+X 2}{2}=\left(\sum_{i=1}^{2} X i\right) / 2 \\
& \text { And for standardization, } \mathrm{I}_{1}=0<\frac{\left(\sum_{i=1}^{2} X i\right) / 2-1}{3}<1
\end{aligned}
$$

Where, $X_{1}$ represents independent decision-making and $X_{2}$ represents the involvement in major household decisions.

\subsubsection{Economic Empowerment Index}

Two indicators have been used for the dimension of economic empowerment. Economic empowerment of women is represented by the following formula:

$$
\begin{aligned}
& \text { Economic empowerment, } \mathrm{I}_{2}=\frac{X 1+X 2}{2}=\left(\sum_{i=1}^{2} X i\right) / 2 \\
& \text { And for standardization, } \mathrm{I}_{2}=0<\frac{\left(\sum_{i=1}^{2} X i\right) / 2-1}{3}<1
\end{aligned}
$$

Where, $X_{1}$ represents income earning potential and $X_{2}$ represents autonomy of choice over how income is spent.

\subsubsection{Social Empowerment Index}

Three indicators have been used for the dimension of social empowerment. Social empowerment of women is represented by the following formula:

$$
\begin{aligned}
& \text { Social empowerment, } \left.\mathrm{I}_{3}=\frac{X 1+X 2+X 3}{3}=\sum_{i=1}^{3} X i\right) / 3 \\
& \text { And for standardization, } \mathrm{I}_{3}=0<\frac{\left(\sum_{i=1}^{3} X i\right) / 3-1}{3}<1
\end{aligned}
$$

Where, $X_{1}$ represents a woman's freedom of mobility, $X_{2}$ represents her participation in a microcredit program, and $X_{3}$ represents a woman's social status.

\subsubsection{Legal Empowerment Index}

One indicator has been used for the dimension of legal empowerment. Legal empowerment of women is represented by the following formula:

$$
\begin{aligned}
& \text { Legal empowerment, } \mathrm{I}_{4}=\frac{X 1}{1}=\left(\sum_{i=1}^{1} X i\right) / 1 \\
& \text { And for standardization, } \mathrm{I}_{4}=0<\frac{\left(\sum_{i=1}^{1} X i\right) / 1-1}{3}<1
\end{aligned}
$$

Where, $X_{I}$ represents the awareness raised about injustices suffered and women's corresponding legal rights.

\subsubsection{Psychological Empowerment Index}

Two indicators have been used for the dimension of psychological empowerment. Psychological empowerment of women is represented by the following formula:

$$
\begin{aligned}
& \text { Psychological empowerment, } I_{5}=\frac{X 1+X 2}{2}=\left(\sum_{i=1}^{2} X i\right) / 2 \\
& \text { And for standardization, } I_{5}=0<\frac{\left(\sum_{i=1}^{2} X i\right) / 2-1}{3}<1
\end{aligned}
$$

Where, $X_{1}$ represents increases gained in confidence and $X_{2}$ represents level of self-respect.

\subsubsection{Overall Women's Empowerment Index}

The overall women's empowerment index was calculated with the following formula:

$$
\text { Overall women empowerment index, } I=\frac{I 1+I 2+I 3+I 4+I 5}{5}
$$

Where, $I_{1}-I_{5}$ represent the standardized levels of empowerment as classified in Decision-making, Economic empowerment, Social empowerment, Legal empowerment, and Psychological empowerment, respectively.

\subsection{Factors Affecting Women's Empowerment through Dairy Farming}

\subsubsection{Specification of the Variables}

The variables that may affect women's empowerment through dairy farming are: the husband's behavior, 
successful reduction of the dependency of rural women, increase knowledge and skill, and breakdown of traditional socio-cultural norms, and types of dairy animal breed (see below).

\subsubsection{Explanation of the Variables}

Types of Breed

This variable was defined by using the following designations: $1=$ local cow and $2=$ crossbred cow.

\section{Husbands' Treatment of their Wives}

This variable was measured by using a 3-point Likert scale with the following designations: $3=$ good, $2=$ moderate and $1=$ bad

\section{Breakdown of Traditional Socio-Cultural Norms}

This variable was further broken down into two categories, namely reduction in domestic violence and reduction in prevalence of early marriage. These variables were measured using a five point Likert scale ranging from $5=$ strongly agree to $1=$ strongly disagree.

Increase in Knowledge and Skill

This variable was assigned $1=$ yes (increase in knowledge and skill) and $0=$ no.

\section{Reducing Dependency of Rural Women}

This variable was assigned $1=$ yes (reduction in dependency) and $0=$ no.

\subsubsection{The Model}

The following multiple linear regression model was used to estimate the effect of the above independent variables on the dependent variable, women's empowerment:

$$
\mathrm{Y}=\beta_{0}+\beta_{1} \mathrm{X}_{1}+\beta_{2} \mathrm{X}_{2}+\beta_{3} \mathrm{X}_{3}+\beta_{4} \mathrm{X}_{4}+\beta_{5} \mathrm{X}_{5}+\mathrm{e}_{\mathrm{i}}
$$

Where, $Y=$ women's empowerment index, $X_{1}=$ types of breed, $X_{2}=$ husband's behavior, $X_{3}=$ breakdown of traditional socio-cultural norms, $X_{4}=$ increase in knowledge and skill and $X_{5}=$ reducing dependency, $\beta_{1}, \beta_{2}, \beta_{3}, \beta_{4}$, and $\beta_{5}$ are the corresponding coefficients, and $e_{i}$ is the error term.

\subsection{Data Analysis}

Data were analyzed using a multiple linear regression model to measure the effects of the different independent variables on women's empowerment. Results were considered at $1 \%, 5 \%$, and $10 \%$ significance levels.

\section{Results and Discussion}

\subsection{Women Empowerment Indicators}

In this study, several empowerment indicators have been used to measure the level of empowerment among women living and working on small-scale dairy farms in two rural Bangladesh villages, V1 and V2. Regarding the different empowerment indicators, the percent distributions of all women's responses are shown in Table 1 (ranging from 1 to 4 ).

Table 1. Percent distribution of V1 and V2 women's response on empowerment indicators

\begin{tabular}{ccccccccc}
\hline & \multicolumn{4}{c}{ V1 } & \multicolumn{4}{c}{ V2 } \\
\cline { 2 - 9 } Women empowerment indicators & $\begin{array}{c}\text { To a great } \\
\text { extent } \\
(\%)\end{array}$ & $\begin{array}{c}\text { To an } \\
\text { average } \\
\text { extent } \\
(\%)\end{array}$ & $\begin{array}{c}\text { To } \\
\text { some } \\
\text { extent } \\
(\%)\end{array}$ & $\begin{array}{c}\text { Not } \\
\text { at } \\
\text { all } \\
(\%)\end{array}$ & $\begin{array}{c}\text { To a } \\
\text { great } \\
\text { extent } \\
(\%)\end{array}$ & $\begin{array}{c}\text { To an } \\
\text { average } \\
\text { extent } \\
(\%)\end{array}$ & $\begin{array}{c}\text { To } \\
\text { some } \\
\text { extent } \\
(\%)\end{array}$ & $\begin{array}{c}\text { Not at } \\
\text { all } \\
(\%)\end{array}$ \\
\hline Independent decision & 54 & 20 & 6 & 20 & 16 & 40 & 26 & 18 \\
Major household decision & 34 & 32 & 12 & 22 & 14 & 24 & 26 & 36 \\
Income earning potential & 42 & 18 & 20 & 20 & 0 & 22 & 54 & 24 \\
Independence in spending money & 24 & 32 & 20 & 24 & 18 & 24 & 26 & 32 \\
Freedom of mobility & 18 & 38 & 44 & - & 10 & 18 & 68 & 4 \\
Participation in microcredit & 22 & 42 & 12 & 24 & 6 & 28 & 54 & 12 \\
Social status & 18 & 34 & 32 & 16 & 6 & 20 & 50 & 24 \\
Injustice and legal right & 22 & 44 & 12 & 22 & 14 & 28 & 28 & 30 \\
Confidence & 42 & 26 & 22 & 10 & 18 & 24 & 32 & 26 \\
Self-esteem & 32 & 22 & 28 & 18 & 8 & 32 & 40 & 20 \\
\hline
\end{tabular}


In general, higher scores for most variables were observed for V1, indicating that women's empowerment was higher in V1 than V2 (see Table 1 and Figure 2).

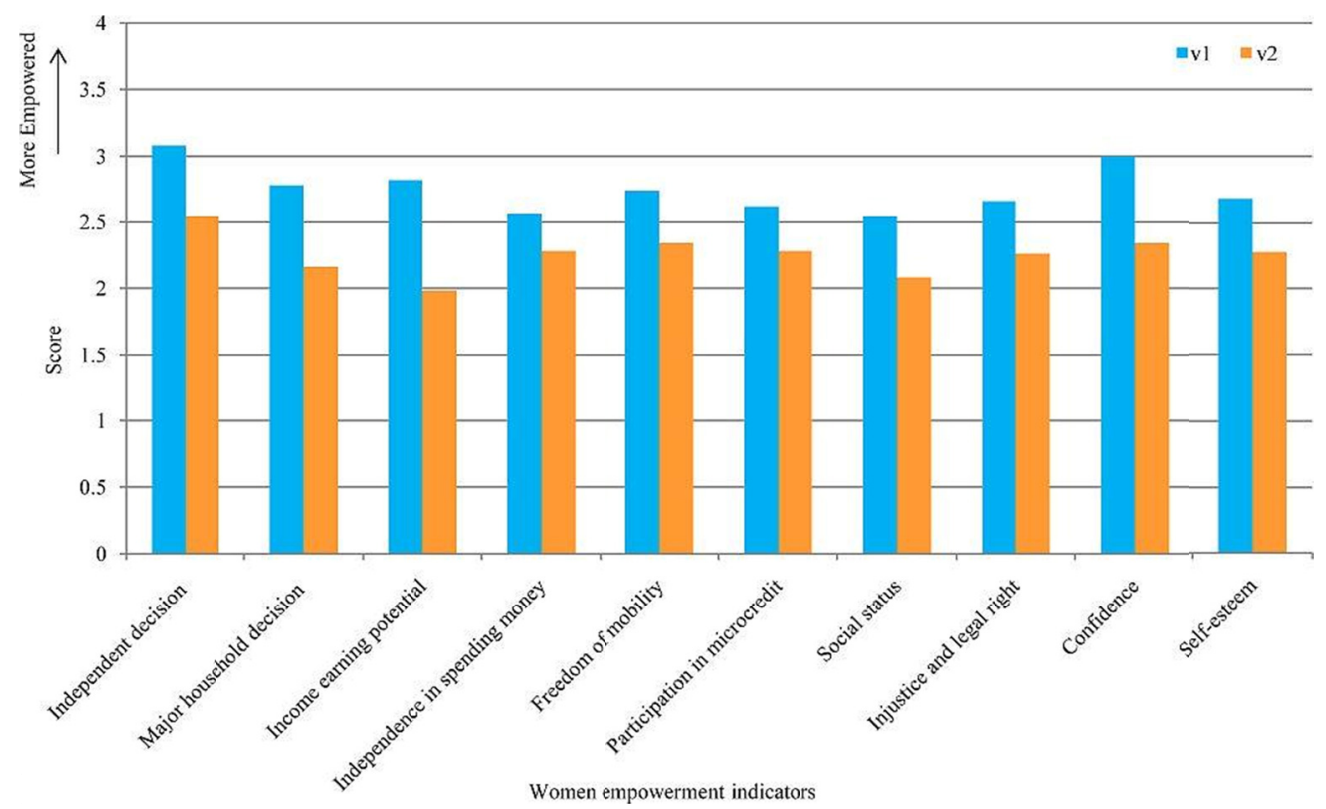

Figure 2. Women's empowerment indicators for V1 and V2

\subsection{Result of Measuring Women Empowerment Index}

A women's empowerment index was been used in this study to measure women's empowerment in V1 and V2. The fitted women's empowerment index of both villages is shown in Figure 3, confirming a higher empowerment index for V1 than V2. V1 women were much more benefitted and empowered than V2 women through their role in rearing small-scale dairy animals. The decision-making, economic and psychological dimension indices were very also more important for V1 women's empowerment than V2 (Figure 3).

\subsubsection{Decision-Making Index}

Independence or autonomy refers to the freedom for expression of a women's personal preference, a freedom of choice when presented with many alternatives, the successful improvement of self-worth, and eventual achievement of target future goals. The higher a woman's level of independence, the greater the potential for her to be empowered (Panda, 2000). Freedom of decision-making plays a substantial role in corresponding quality of life for women, and here we used two indicators to quantify the dimension of decision-making: 1) the power of taking independent decisions and 2) the extent of involvement in major household decisions. By comparing these factors between the two villages, from the Figure 3, it was found that decision-making index was higher in V1 (0.64) than V2 (0.45). Women in V1 have more power to make independent decisions and work freely than do women in $\mathrm{V} 2$.

In V1, historically the lives of the women have been dominated by a patriarchal social system and upon marriage, typically a woman is expected to obey all the rules mandated by her husband, is prohibited from making independent decisions, and has no right to challenge her husband's authority. All decisions regarding activities within and outside of the household are made solely by male members (Mujahid et al., 2015). During childhood, women are dependent on male family members and not educated or taught self-dependency. Upon marriage, bearing children, and in particular a son becomes a prime responsibility for these women, along with household duties such as cooking for family members. This historical treatment of women has changed notably within V1 with the advent of small-scale dairy farming, however, and women's sense of self and self-determination has increased. Through our research we found that rural women in V1 served significant decision-making roles in family affairs, including decisions about their own health and the health of their children. In particular, in the face of sickness, pregnancy, or related health matters, the women in V1 were able to choose independently to visit a hospital or health clinic. Women were also allowed to make decisions regarding the health and general care of their children, such as choosing to vaccinate their newborns, making nutritious food choices, and opting to seek better treatment for their sick children. The women from V1 also exhibited increased expression of 
personal preference and had the freedom to make good daily food and nutritional choices for their family and had similar authority in deciding how to feed their dairy cattle to improve productivity. The women were also involved in major family decision-making on issues related to family members, the marriage of a son or daughter, household repairs, and large purchases. In contrast, women in V2 had few decision-making rights within the family because they had little autonomy and power. Ultimately, the increased decision-making power exhibited by the women in V1 is representative of significant progress toward the achievement of gender balance in their society.

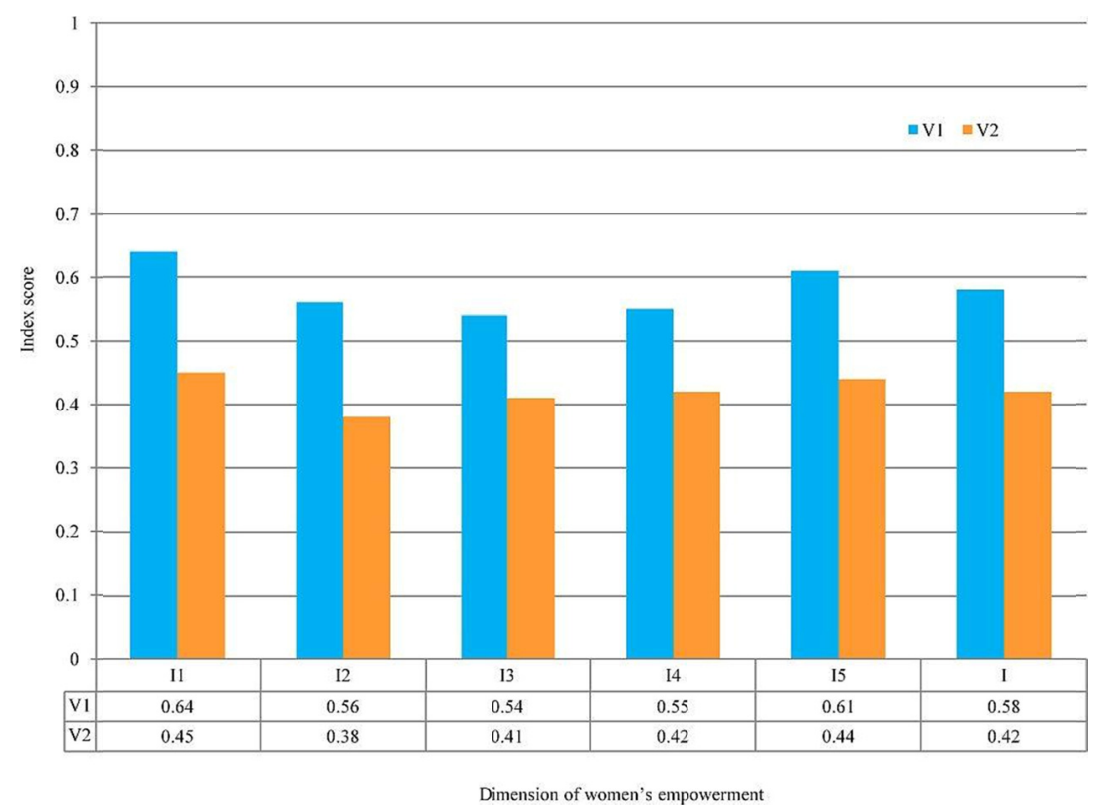

Figure 3. Women's empowerment index of V1 and V2

Note 1) Different women's empowerment dimension index scores, where the empowerment index score ranges between 0 and 1

\subsubsection{Economic Empowerment Index}

Economic empowerment is another significant dimension of women's empowerment and research has suggested that economic empowerment of women enhances through their participation in economic activities (Parveen \& Chowdhury, 2009). Rural women involved in income-generating activities experience greater empowerment rather who are not engaged in any economic activity (Nessa et al., 2012). From the results gathered in this study, the economic empowerment index was found to be higher for women in V1 (0.56) than V2 (0.38). V1 women earned much more money from dairy farming than the women in V2, due to their ability to provide adequate nutrition to dairy cattle and thereby improve farm productivity. The economic decisions the women make in dairy farming also foster independence with regard to making other expenditures for their family, on items such as clothing or medicine. In contrast, V2 women did not have autonomy in financial decisions surrounding the care of their dairy cattle and did not exhibit the same economic success as women in V1.

\subsubsection{Social Empowerment Index}

Social empowerment is the process of accessing opportunities and resources in order to make personal choices. Poor rural women are socially empowered through the improvement of their practical knowledge, self-perception, and physical mobility and this process serves to remove social barriers and obstacles. Social empowerment among the women in V1 and V2 was quantified by considering three indicators: mobility, participation in a microcredit program and social status. As can be seen in Figure 3, social empowerment was determined to be higher in V1 (0.54) than V2 (0.41). Indeed, women from V1 exhibited greater freedom of mobility than women from V2 and were able to leave their home and visit the market, health care center, or the house of a neighbor or relative without permission from their husband or other elder members of the family. Following their involvement in dairy farming, the women were able to extend their social network and mobility, increase communication with those outside of their family, and develop further independence. For many women in V2, we found that permission is still required for going outside of the home and their mobility is restricted. Women in both villages also participate in the microcredit program, where they can interact with other women 
and exchange knowledge, skills, and experiences. Research evidence has previously demonstrated that microcredit programs can improve the productivity and development of income-generating activities (Alhassan \& Akudugu, 2012), thus the women who partake in these programs they are more socially empowered than their peers who do not partake (Awojobi, 2014). Involvement in the microcredit program did expand the social network of women in V1 and enhance their social status and social recognition. However, for the women in V2, participation in the microcredit program did not lead to the same social empowerment.

\subsubsection{Legal Empowerment Index}

Following the above trend, the legal empowerment index was also found to be higher in V1 (0.55) than V2 (0.42). Since becoming involved with dairy farming, V1 women are now more conscious of their legal rights. Through the process of earning money and using this income for family purchases, the women acquired bargaining skills and could express their differing opinions and disagree with their husband or other family members. Banu et al. (2001) have shown that rural women who involved in Bangladesh Rural Advancement Committee's Program, are able to acquire more knowledge of property rights and other legal issues such as lawful marriage age, dowries, and divorce. For example, some women learned that it is illegal for their husbands to remarry without the first wife's consent. In contrast, many women from V2 are less conscious about their legal rights and powerless to seek them.

\subsubsection{Psychological Empowerment Index}

Psychological empowerment is vital for the development of poor rural women in Bangladesh. The results revealed that women in V1 have experienced an increase in their confidence level and this has helped to enhance their efficiency and productivity in dairy farming. Level of self-respect is another important indicator for psychological empowerment, and in comparison with women from V2, V1 women exhibited an increase in self-respect and enhanced status in their family after becoming involved with dairy farming. In V2, the patriarchal social system is still strong and the women are dependent on their family, have limited self-confidence, and are less inclined to take initiative. Including the psychological empowerment index with the others above, we find overall that the empowerment index in V1 (0.58) is higher than V2 (0.42).

\subsection{Factors Affecting Rural Women's Empowerment through Small-Scale Dairy Farming}

Table 2. Descriptive statistics

\begin{tabular}{|c|c|c|c|c|c|c|c|c|}
\hline \multirow{2}{*}{\multicolumn{3}{|c|}{ Variables with category }} & \multicolumn{3}{|c|}{$\mathrm{V} 1$} & \multicolumn{3}{|c|}{$\mathrm{V} 2$} \\
\hline & & & \multirow{3}{*}{$\begin{array}{c}\text { Frequency } \\
\begin{array}{c}19 \\
31\end{array}\end{array}$} & \multirow{3}{*}{$\begin{array}{c}\text { Percent } \\
38.0 \\
62.0\end{array}$} & \multirow{3}{*}{$\frac{\text { Mean }}{1.62}$} & \multirow{3}{*}{$\begin{array}{c}\text { Frequency } \\
50 \\
0\end{array}$} & \multirow{3}{*}{$\begin{array}{c}\text { Percent } \\
100.0 \\
0.0\end{array}$} & \multirow{3}{*}{$\begin{array}{l}\text { Mean } \\
1.00\end{array}$} \\
\hline \multirow[t]{2}{*}{ Types of breed } & \multirow{2}{*}{\multicolumn{2}{|c|}{$\begin{array}{c}\text { Local } \\
\text { Crossbred }\end{array}$}} & & & & & & \\
\hline & & & & & & & & \\
\hline \multirow{3}{*}{$\begin{array}{l}\text { Husband's } \\
\text { behavior }\end{array}$} & \multicolumn{2}{|c|}{ Good } & 33 & 66.0 & & 4 & 8.0 & \\
\hline & \multicolumn{2}{|c|}{ Moderate } & 9 & 18.0 & 2.50 & 16 & 32.0 & 1.48 \\
\hline & \multicolumn{2}{|c|}{ Bad } & 8 & 16.0 & & 30 & 60.0 & \\
\hline \multirow{10}{*}{$\begin{array}{l}\text { Breakdown of } \\
\text { traditional } \\
\text { socio-cultural } \\
\text { norms }\end{array}$} & \multirow{5}{*}{$\begin{array}{l}\text { Reduce } \\
\text { violence }\end{array}$} & $\begin{array}{l}\text { Strongly } \\
\text { agree }\end{array}$ & 23 & 46.0 & \multirow{5}{*}{4.00} & 0 & 0.0 & \multirow{5}{*}{2.36} \\
\hline & & Agree & 15 & 30.0 & & 4 & 8.0 & \\
\hline & & Undecided & 1 & 2.0 & & 11 & 22.0 & \\
\hline & & Disagree & 11 & 22.0 & & 34 & 68.0 & \\
\hline & & $\begin{array}{l}\text { Strongly } \\
\text { disagree }\end{array}$ & 0 & 0.0 & & 1 & 2.0 & \\
\hline & \multirow{5}{*}{$\begin{array}{c}\text { Reduce early } \\
\text { marriage }\end{array}$} & $\begin{array}{l}\text { Strongly } \\
\text { agree }\end{array}$ & 30 & 60.0 & \multirow{5}{*}{4.48} & 0 & 0.0 & \multirow{5}{*}{1.90} \\
\hline & & Agree & 15 & 30.0 & & 4 & 8.0 & \\
\hline & & Undecided & 4 & 8.0 & & 3 & 6.0 & \\
\hline & & Disagree & 1 & 2.0 & & 27 & 54.0 & \\
\hline & & $\begin{array}{l}\text { Strongly } \\
\text { disagree }\end{array}$ & 0 & 0.0 & & 16 & 32.0 & \\
\hline \multirow{2}{*}{$\begin{array}{c}\text { Increase in } \\
\text { knowledge and } \\
\text { skill }\end{array}$} & \multicolumn{2}{|c|}{ Yes } & 37 & 74.0 & \multirow{2}{*}{0.74} & 15 & 30.0 & \multirow[b]{2}{*}{0.30} \\
\hline & \multicolumn{2}{|c|}{ No } & 13 & 26.0 & & 35 & 70.0 & \\
\hline \multirow{2}{*}{$\begin{array}{c}\text { Reduce } \\
\text { dependency }\end{array}$} & \multirow{2}{*}{\multicolumn{2}{|c|}{$\begin{array}{l}\text { Yes } \\
\text { No }\end{array}$}} & 32 & 64.0 & \multirow{2}{*}{0.64} & 13 & 26.0 & \multirow{2}{*}{0.26} \\
\hline & & & 18 & 36.0 & & 37 & 74.0 & \\
\hline
\end{tabular}


A multiple linear regression model was used to estimate the effects of different factors on women's empowerment through small-scale dairy farming in two villages. Table 2 presents the descriptive statistics of independent variables which were used for analysis.

The results of multiple linear regression analysis are shown in Table 3. Types of breed were considered in this model as an important determinant for women empowerment in V1. The sign of its coefficient was found to be positive and significant, specifically the women in $\mathrm{V} 1$ were more conscious about dairy farming and wanted to maximize their profits and thus they started to rear crossbred cattle. In V1, the majority of the respondents (62\%) reared crossbred cattle (Table 2). This type of cattle is more productive compared to local cattle raised by women in V2. By earning more money from dairy farming through their choice of cattle, the women of V1 were more empowered.

Table 3. Results of factors affecting women's empowerment in both villages

\begin{tabular}{lcccc}
\hline \multirow{2}{*}{ Predictors } & \multicolumn{2}{c}{ Standardized Coefficient(Beta) } & \multicolumn{2}{c}{ Sig. } \\
\cline { 2 - 4 } & $\mathrm{V} 1$ & $\mathrm{~V} 2$ & $\mathrm{~V} 1$ & $\mathrm{~V} 2$ \\
\hline Constant & - & - & 0.000 & 0.605 \\
Types of breed & $0.330(4.814)$ & - & $0.000^{* * *}$ & - \\
Husband's behavior & $0.282(4.534)$ & $0.210(1.473)$ & $0.000^{* * *}$ & 0.148 \\
Breakdown of traditional socio-cultural norms & $0.269(4.480)$ & $0.181(1.278)$ & $0.000^{* * *}$ & 0.208 \\
Increase in knowledge and skill & $0.187(2.971)$ & $0.162(1.169)$ & $0.005^{* * *}$ & 0.248 \\
Reduce dependency & $0154(2.176)$ & $0.097(0.695)$ & $0.035^{* *}$ & 0.490 \\
$\mathrm{R}^{2}$ & 0.899 & 0.135 & & \\
Adjusted $\mathrm{R}^{2}$ & 0.887 & 0.058 & & \\
Durbin-Watson stat & 1.746 & 1.531 & & \\
\hline
\end{tabular}

Dependent variable: Y (women's empowerment index)

Note 1$) * * *$ indicates significance at $1 \%$ level, ** indicates significance at $5 \%$ level and $*$ indicates significance at $10 \%$ level and $t$ values are in parenthesis

Note 2) Source: Primary data analysis, 2014

In V1, the husband's behavior was found statistically significant in women's empowerment (Table 3). In rural areas of Bangladesh, traditionally husbands do not allow their wives to participate in family or major household decisions. Rural women married to especially patriarchal and controlling husbands have been constrained in pursuing empowerment (Schuler et al., 2010). More recently, however, traditional ways of thinking are changing among V1 women. For example, women in V1 now have the right to spend the family income and make decisions independent of permission from their husband or other male members of the family. Similar social progress is stalled in V2 and women have little influence in personal and household matters. Women receive little respect from their husbands and the family-in-law may even consider the wife and her children as expense burdens on the husband, contributing to family conflict. It was observed from Table 2 , with the majority of the respondents ( $66 \%$ from $\mathrm{V} 1$ ) reporting good behavior from their husbands while a higher percentage of respondents (60\% from V2) reported bad behavior from their husbands. Particularly in V1, women's involvement in dairy farming is fostering a desire for independence. Their husbands are supportive of these efforts, recognizing the financial support the women can bring to the family. Therefore, in V1, rural women are being empowered through small-scale dairy farming and able to redefine their position in their family. The husbands' supportive behavior towards their wives is therefore an important factor for women's empowerment in V1. Research evidence has also previously reported that when women are allowed to start and run their own business, their status in the family improves considerably (Islam et al., 2012).

The breakdown of traditional socio-cultural norms was observed to be another important factor contributing to the greater empowerment of women in V1 (Table 3). Before beginning dairy farming, the primary role of these women was as housewives and they had no independence. According to Parveen and Leonhauser (2004), the most common forms of domestic violence against women at the hands of their husband or family include physical abuse, threats of divorce from the husband, unwillingness from the husband to provide family support, and mental abuse. All these can have a serious negative consequence on women's health and quality of life and prevent empowerment. Since participating in income-generating activities such as dairy farming, however, these women play a more active role in family finances and acquire some bargaining power within their family, thus 
diminishing the prior gender inequality and providing some protection against domestic violence. In V1, the majority of the respondents $(46 \%)$ strongly agreed that violence against them have been reduced (Table 2$)$. The women were also able to increase their mobility, develop more interpersonal interactions, and through exposure to the media (via television), are made more aware of illegal treatment at the hands of their husbands and may seek to demand their rights

Another consequence of women's involvement in dairy farming is the increased awareness of education and in particular the importance of educating girls from a young age. Previously, early marriages were a predominant factor preventing the education of young girls and stalling any empowerment process (Hossain, 2011). Additionally, early marriages could often lead to early motherhood and various health risks to mother and child. The prevalence of early marriage has now begun to decrease as education level has increased, leading also to improved health among young women. Additionally, previously it was a common perception that sons were more valuable than daughters and were more capable of supporting the family and caring for parents in old age (Parveen \& Leonhauser, 2004). Women might suffer abuse at the hands of their husbands for bearing a female child, and would be coerced to continue to carry children until successfully bearing a son. Women now have more control over the number of children and pregnancies they have, which has led to an overall improvement in the health of the women from V1. This social and cultural progress has not been made in V2, where early marriages and repeated pregnancies are still common and gender discrimination is still prevalent. In V2, the majority of the respondents (54\%) disagreed that early marriage was reduced (Table 2).

Overall women in V1 experienced an increase in knowledge and skill through small-scale dairy farming (Table 3 ). It was observed that $74 \%$ of the respondents increased their knowledge, skill and capability through dairy farming in V1 (Table 2). In addition to factors such as access to television and mobile phones, the V1 is situated near Bangladesh Agricultural University, and thus women are able to seek input from professors, veterinary surgeons, and Artificial Insemination (AI) center scientists to improve their farming ability. Research evidence has already shown such learning and proactive involvement in business decision-making is profitable for dairy farming (Ogdand \& Hembade, 2014). The inhabitants of V2 are not located near the University, and have no easy access to this additional tool for improving their farming capabilities.

As also shown in Table 3, the income earned through dairy farming has reduced the dependency of women from $\mathrm{V} 1$ relative to women in V2, as the women in V1 no longer need the same financial support from their husbands. It was observed that $64 \%$ of the respondents in V1 reduced their dependency and in V2, lowest percentage of the respondents $(26 \%)$ reduced dependency (Table 2). Indeed, research evidence has shown that if Bangladeshi women in are gainfully employed outside the household, their contributions to the household are not only more visible but their economic dependence on their husbands is decreased (Kamal et al., 1992). The women also have more freedom to make decisions, go to the market, and make purchases without approval, as research evidence has shown previously for Bangladeshi women (Banu et al., 2001).

\section{Conclusions}

From this study, we have observed that small-scale dairy farming is increasing empowerment among women in V1, though less progress has been made in V2. Rural women in V1 are more empowered than women from V2 with regard to decision-making, in achieving economic, social, and legal rights, and are experiencing more general psychological growth. The greatest factors influencing this empowerment among women in V1 were the support from the husband, the successful breakdown of traditional cultural norms, the ability to increase knowledge and skill, and finally the breed of cattle raised. While these factors were not as significant for the women in V2, we still observed a positive correlation between dairy farming and the above factors. Overall, we find empirically that the women of V1 are more empowered through small-scale dairy farming than the women of $\mathrm{V} 2$.

These findings have important implications for the potential substantive role of small-scale dairy farming in other rural areas of Bangladesh. By encouraging and promoting small-scale dairy farming in additional rural communities, gender inequality may be further diminished and correspondingly more women may be empowered. Such economic activity has the potential to reduce the prevalence of early marriages, decrease spousal abuse, and foster the development of new practical knowledge, skills, and confidence, thus making an important contribution to the improved female status in families and society.

\section{Acknowledgements}

This study has been conducted through the support of Tokyo University Fellowship (Todai Fellowship), Japan. The authors gratefully acknowledge Nokibullah Siddique, District Livestock Officer (DLO), Bangladesh, for providing the necessary facilities and information to conduct this study. The authors are also thankful to the 
women dairy farmers in both villages for their huge support during the period of data collection.

\section{References}

Afzal, A., Ali, T., Ahmad, M., Zafar, M. I., Niazi, S. K., \& Riaz, F. (2009). Identification of factors hampering women empowerment in agricultural decision-making and extension work in district Okara, Punjab, Pakistan.Pakistan Journal of Agricultural Science, 46(1), 64-68. Retrieved from http://www.pakjas.com.pk/papers/126.pdf

Alhassan, A. R., \& Akudugu, M. A. (2012). Impact of microcredit on income generation capacity of women in the Tamale Metropolitan area of Ghana.Journal of Economics and Sustainable Development, 3, 41-48.

Awojobi, O. N. (2014). Empowering women through micro finance: Evidence from Nigeria. Australian Journalof Australian Journal of Business and Management Research, 4(1), 17-26.

Banu, D., Farashuddin, F., Hossain, A., \& Akter, S. (2001). Empowering women in rural Bangladesh: Impact of Bangladesh Rural Advancement Committee's (BRAC's) Program. Journal of International Women's Studies, 2(3), 30-53. Retrieved from http://vc.bridgew.edu/jiws/vol2/iss3/3

Batliwala, S. (1994). The meaning of women's empowerment: New concepts from action. In Population policies reconsidered: Health, empowerment and rights. Harvard University, Harvard Center for Population and Development Studies (pp. 127-138).

Charmus, J., \& Wieringa, S. (2003). Measuring empowerment: An assessment of the gender related development index and the gender empowerment measure. Journal of Human Development and Capabilities, 4(3), 419-435. Retrieved from http://dx.doi.org/10.1080/1464988032000125773

Haque, M. M., Islam,T. M., Tareque, M. I., \& Mostofa, M. G. (2011). Women empowerment or autonomy: A comparative view in Bangladesh context. Bangladesh e-Journal of Sociology, 8(2), 17-98.

Hashemi, S. M., \& Schuler, S. R. (1993). Defining and studying empowerment of women: A research note from Bangladesh. JSI Working Paper No. 3. Washington DC: John Snow, Inc.

Hashemi, S. M., Schuler, S. R., \& Riley, A. P. (1996). Rural credit programs and women's empowerment in Bangladesh.World Development, 24(4), 635-653. http://dx.doi.org/10.1016/0305-750X(95)00159-A

Hossain, M. A. (2011). Socio-economic obstacles of women empowerment in rural Bangladesh: A study on Puthiaupazila of Rajshahi district. Research on Humanities and Social Sciences, 1(4), 1-13.

Islam, N., Ahmed, E., Chew, J., \& D’Netto, B. (2012). Determinants of empowerment of rural women in Bangladesh. World Journal of Management, 4(2), 36-56. Retrieved from http://www.wbiaus.org/7.\% 20Brian.pdf

Islam, M. S., Ahmed, M. F., \& Alam, M. S. (2014). The role of microcredit program on women empowerment: Empirical evidence from rural Bangladesh. Developing Country Studies, 4(5), 90-97.

Kabeer, N. (1999). Resources, agency, achievements: Reflections on the measurement of women's empowerment. Development and Change, 30, 435-464. http://dx.doi.org /10.1111/1467-7660.00125

Kamal, G. M., Rahman, M. B., \& Ghani, A. K. M. A. (1992). Impact of credit on reproductive behavior of Grameen Bank women beneficiaries. Associates for Community and Population Research, Dhaka, Bangladesh.

Keller, B., \& Mbwewe, D. C. (1991). Policy and planning for the empowerment of Zambia's women farmers. Canadian Journal of Development Studies, 12(1), 75-88. http://dx.doi.org/10.1080/02255189.1991.9669421

Kishor, S., \& Gupta, K. (2004). Women's empowerment in India and its States: Evidence from the NFHS. Economic and Political Weekly, 39(7), 694-712. http://dx.doi.org/10.2307/4414645

Kishore, S., \& Lekha, S. (2008). Understanding women's empowerment: A comparative analysis of Demographic Health Surveys (DHS) Data. DHS Comparative Report No.20, Calverton, Maryland, USA: Macro International INC.

Kumar, D., Hossain, A., \& Gope, M. C. (2013). Role of microcredit program in empowering rural women in Bangladesh: A Study on Grameen Bank Bangladesh Limited. Asian Business Review, 3(4), 114-120.

Mahmud, S., Shah, N. M., \& Becker, S. (2012). Measurement of women's empowerment in rural Bangladesh. World Development, 40(3), 610-619. http://dx.doi.org/10.1016/j.worlddev.2011.08.003

Malhotra, A. (2003). Conceptualizing and measuring women's empowerment as a variable in International 
development. World Bank Workshop on Measuring Empowerment: Cross-Disciplinary Perspectives, Washington, DC on February 4 and 5.

Mujahid, N., Ali, M., Noman, M., \& Begum, M. (2015). Dimensions of women empowerment: A case study of Pakistan. Journal of Economics and Sustainable Development, 6(1), 37-45.

Nazneen, S., Hossain, N., \& Sultan, M. (2011). National discourses on women's empowerment in Bangladesh: Continuities and change. Institute of Development Studies, 2011(368). Retrieved from http://dx.doi.org/10.1111/j.2040-0209.2011.00368_2.x

Nessa, T., Ali, J., \& Hakim, A. R. (2012). The impact of microcredit programs on women empowerment: Evidence from Bangladesh. OIDA International Journal of Sustainable Development, 3(9), 11-20. Retrieved from http://ssrn.com/abstract=2034583

Ogdand, G. G., \& Hembade, A. S. (2014). Studies on the participation of women in decision-making about dairy occupation in Parbhani district of Maharashtra state. International Journal of Current Research and Academic Review, 2(8), 367-372. Retrieved from www.ijcrar.com.

Page, N., \& Czuba, C. E. (1999). Empowerment: What Is It? Journal of Extension, 37(5).

Parveen, S., \& Leonhauser, I. U. (2004). Empowerment of rural women in Bangladesh: A household level analysis. Conference on rural poverty reduction through research for development transformation, Deutscher Tropentag-Berlin, 5-7 October.

Parveen, S., \& Chaudhury, M. R. (2009). Microcredit intervention and its effects on empowerment of rural women: The BRAC experience. Bangladesh Research Publications Journal, 2(3), 641-647.

Panda, S. M. (2000). Women's empowerment through NGO interventions: A framework for assessment. Institute of Rural Management, Anand, Gujarat, India. Retrieved from http:// Irma.ac.in

Shefner-Rogers, C. L., Rao, N., Rogers, E. M., \& Wayangankar, A. (2009). The empowerment of women dairy farmers in India. Journal of Applied Communication Research, 26(3), 319-337. Retrieved from http://dx.doi.org/10.1080/00909889809365510

Schuler, S. R., Islam, F., \& Rottach, E. (2010). Women's empowerment revisited: A case study from Bangladesh. Journal of Development in Practice, 20(7), 840-854. Retrieved from http://dx.doi.org/10.1080/00220380 903318095

Sultana, A., \& Hossen, S. K. S. (2013). Role of employment in women empowerment: Evidence from Khulna City of Bangladesh. International Journal of Social Science and Interdisciplinary Research, 2(7), 117-125.

Sen, A. (1999). Development as Freedom. Oxford: Oxford University Press.

\section{Copyrights}

Copyright for this article is retained by the author (s), with first publication rights granted to the journal.

This is an open-access article distributed under the terms and conditions of the Creative Commons Attribution license (http://creativecommons.org/licenses/by/3.0/). 